\title{
Perbedaan Kadar Hemoglobin, Nilai Hematokrit Dan Jumlah Eritrosit Pada Pasien Stroke Hemoragik Dan Stroke Non Hemoragik Di RSUD Dr. H. Abdul Moeloek Provinsi Lampung
}

\author{
Maria Tuntun ${ }^{1}$, Wiranto Basuki ${ }^{2}$, Fika Yustisi Amalia ${ }^{3}$, \\ Prodi Diploma III Analis Kesehatan Poltekkes Tanjungkarang \\ ${ }^{2}$ RSU. Urip Sumoharjo Bandarlampung \\ ${ }^{3}$ Alumni Prodi Diploma IV Analis Kesehatan Poltekkes Tanjungkarang
}

\begin{abstract}
Abstrak
Stroke merupakan penyakit atau gangguan fungsional otak berupa kelumpuhan saraf (deficit neurologic) akibat terhambatnya aliran darah ke otak secara mendadak dan akut yang berlangsung lebih dari 24 jam, karena adanya perdarahan ataupun sumbatan pada bagian otak yang dapat menyebabkan kematian. Penyakit stroke dapat menyebabkan terjadinya viskositas/kekentalan darah yang dapat memperburuk kejadian stroke, menyebabkan perlambatan aliran darah otak, perluasan infark, dan perburukan prognosis. Penelitian ini bertujuan untuk mengetahui perbedaan kadar hemoglobin, nilai hematokrit dan jumlah eritrosit pada pasien stroke hemoragik dan stroke non hemoragik di RSUD dr. H. Abdul Moeloek Provinsi Lampung. Jenis penelitian berupa analitik dengan desain penelitian cross sectional dan menggunakan uji analisa Independent Sample T Test. Penelitian dilakukan di RSUD dr. H. Abdul Moeloek Provinsi Lampung pada bulan Mei-Juni 2018. Responden penelitian berjumlah 60 pasien dengan rincian 30 pasien stroke hemoragik dan 30 pasien stroke non hemoragik. Hasil penelitian didapatkan $p$-value untuk kadar hemoglobin $=0.004$, nilai hematokrit $=0.004$, dan jumlah eritrosit $=$ 0.026, sehingga dapat disimpulkan bahwa ada perbedaan kadar hemoglobin, nilai hematokrit dan jumlah eritrosit pada pasien stroke hemoragik dengan stroke non hemoragik.
\end{abstract}

Kata Kunci : Hemoglobin, Hematokrit, Eritrosit, Stroke Hemoragik, Stroke Non Hemoragik.

\section{Difference Hemoglobin Levels, Value Of Hematocrit And Amount Of Erythrocytes On Hemorrhagic Stroke And Non Hemorrhagic Stroke In RSUD Dr. H. Abdul Moeloek Provinsi Lampung}

\begin{abstract}
Stroke is a disease or functional disorder of the brain in the form of neurologic nerve (deficit neurologic) due to suddenly inhibition of blood flow to the brain and acute that lasted more than 24 hours, because of bleeding or blockage in the brain that can cause death. Stroke can cause viscosity / blood viscosity which can worsen stroke, cause slowing of cerebral blood flow, infarct extension, and worsening prognosis. This study aims to determine differences in hemoglobin levels, value of hematocrit and amount of erythrocytes in patients with hemorrhagic stroke and non hemorrhagic stroke in dr. H. Abdul Moeloek Provinsi Lampung. The type of research is analytic with cross sectional study design and using Independent Sample T Test. The research was conducted in RSUD dr. H. Abdul Moeloek Provinsi Lampung In May-June 2018. The study respondents were 60 patients with details of 30 hemorrhagic stroke patients and 30 non hemorrhagic stroke patients. The result of this research is $p$-value of hemoglobin value $=0.004$, hematocrit value $=0.004$ and total erythrocyte $=0.026$, so it can be concluded that there are different hemoglobin, hematocrit and erythrocytes in patients with hemorrhagic stroke with non hemorrhagic stroke.
\end{abstract}

Keywords : Hemoglobin, Hematocrit, Erythrocytes, Hemorrhagic Stroke, Non Hemorrhagic Stroke

Korespondensi : Maria Tuntun S, M.Biomed, Jurusan Analis Kesehatan Politeknik Kesehatan Tanjungkarang, J1. Soekarno-Hatta No. 1 Bandar Lampung, mobile: 085279583168,e-mail: maria_tuntun@yahoo. 


\section{Pendahuluan}

Stroke merupakan penyakit atau gangguan fungsional otak berupa kelumpuhan saraf (deficit neurologic) akibat terhambatnya aliran darah ke otak secara mendadak dan akut yang berlangsung lebih dari 24 jam, karena adanya perdarahan ataupun sumbatan pada bagian otak yang dapat menyebabkan kematian (Junaidi, 2011).

Penyakit stroke merupakan salah satu masalah kesehatan yang menempati kedudukan ketiga dalam urutan penyebab kematian, setelah penyakit jantung dan keganasan (kanker) baik di negara maju maupun negara berkembang. Berdasarkan data World Health Organization (WHO) tahun 2012 sebanyak 17.5 juta kematian disebabkan oleh penyakit kardiovaskuler, dengan jumlah estimasi sebanyak 7.4 juta kematian disebabkan oleh penyakit jantung dan 6.7 juta kematian disebabkan oleh penyakit stroke (WHO, 2014).

Berdasarkan data Riskesdas tahun 2013, stroke merupakan penyakit tidak menular yang merupakan penyebab utama kematian di Indonesia. Prevalensi stroke di Indonesia berdasarkan diagnosis tenaga kesehatan sebanyak 1.236 .825 orang $(7,0 \%)$ dan berdasarkan diagnosis tenaga kesehatan/gejala sebanyak 2.137.941 orang $(12,1 \%)$. Berdasarkan diagnosis tenaga kesehatan maupun diagnosis/gejala, Provinsi Jawa Barat memiliki estimasi jumlah penderita terbanyak yaitu sebanyak 238.001 orang $(7,4 \%$ o) dan 533.895 orang $(16,6 \%$ ), sedangkan Provinsi Papua Barat memiliki jumlah penderita paling sedikit yaitu sebanyak 2.007 orang $(3,6 \%)$ dan 2.955 orang $(5,3 \%)$ (Riskesdas, 2013; Pusdatin, 2014).

Prevalensi kejadian stroke di Provinsi Lampung berdasarkan diagnosis tenaga kesehatan sebanyak 42.851 orang $(7,7 \%$ ) dan berdasarkan diagnosis/gejala sebanyak 68.393 orang (12,3\%o) (Pusdatin, 2014).

Menurut Kabupaten/Kota di Propinsi Lampung, prevalensi kejadian stroke berkisar antara 2,2- 10,5\% . Kotamadya Bandar Lampung mempunyai prevalensi lebih tinggi dibandingkan dengan Kotamadya/Kabupaten yang ada di Propinsi Lampung, baik berdasarkan diagnosis maupun berdasarkan gejala (Riskesdas, 2009).

Penyakit stroke ditemukan pada semua golongan usia dan insiden meningkat dengan bertambahnya usia. Stroke umumnya dikenal dua macam yaitu stroke hemoragik disebabkan oleh pecahnya pembuluh darah di otak, sehingga terjadi perdarahan di otak, sedangkan stroke non hemoragik atau iskemik merupakan stroke yang terjadi jika aliran darah ke otak terhambat atau tersumbat. Pecah dan sumbatan pada pembuluh darah menyebabkan aliran darah yang membawa oksigen dan pasokan nutrisi ke otak akan berkurang sehingga menyebabkan stroke (Ardhilla dkk, 2012). Faktor risiko terbesar timbulnya stroke, yaitu merokok, hipertensi, hiperkolesterol, diabetes mellitus, tingginya jumlah sel eritrosit, gangguan pembuluh darah, kegemukan (obesitas), kurangnya aktifitas fisik/olahraga, minuman alkohol (cinnar, 1999; Ardhilla dkk, 2012; Junaidi, 2011).

Faktor-faktor risiko tersebut selain menyebabkan pembentukan aterosklerosis sebagai penyebab utama penyakit stroke, juga dapat menyebabkan terjadinya viskositas/ kekentalan darah yang dapat memperburuk kejadian stroke. Kondisi peningkatan viskositas/kekentalan darah dapat menyebabkan perlambatan aliran darah otak, perluasan infark, dan perburukan prognosis. Viskositas/ kekentalan darah merupakan keadaan hiperkoagulasi darah, berupa adanya peningkatan kepekatan darah yang berlebihan. Peningkatan viskositas darah mengakibatkan gangguan transportasi darah yang membawa oksigen dan nutrisi ke sel-sel otak dan seluruh tubuh menjadi terhambat, apabila berlangsung terus menerus menyebabkan sel otak menjadi kekurangan oksigen dan nutrisi yang akan berakhir pada kematian sel otak dan dapat menyebabkan stroke (Mardjono dkk, 2004; Ardhilla dkk, 2012; Junaidi, 2011).

Peningkatan viskositas/kekentalan darah dapat menyebabkan peningkatan tekanan aliran darah pada pembuluh arteri jantung yang sama dengan tekanan yang berada di pembuluh arteri otak. Tekanan yang terus menerus dapat menyebabkan pecahnya pembuluh darah arteri di otak sehingga dapat menyebabkan stroke hemoragik, selain itu dapat menyebabkan trombosis dengan terbentuknya trombus dan emboli. Trombus tersebut dapat menyumbat pembuluh darah pada otak sehingga mengakibatkan terhentinya suplai darah ke otak yang menyebabkan defisit oksigen. Kerusakan pada bagian otak tersebut dapat menyebabkan stroke non hemoragik/iskemik (Mardjono dkk, 2004; Setiabudy, 2012).

Viskositas/kekentalan darah pada penderita stroke dapat dilihat berdasarkan hasil pemeriksaan hematologi darah berupa adanya peningkatan kadar hemoglobin, nilai hematokrit 
dan jumlah eritrosit dari nilai normal yang dilakukan di laboratorium (Setiabudy, 2012; Cinar dkk, 1999).

Penelitian Hutajalu I, N dkk tahun 2015 mengenai gambaran hematokrit pada pasien stroke iskemik di Rumah Sakit Umum Daerah Arifin Ahmad Provinsi Riau berkesimpulan bahwa sebanyak $68.54 \%$ pasien stroke iskemik memiliki nilai hematokrit yang normal. Penelitian Sholicati S, dkk tahun 2016 terdapat hubungan yang bermakna kadar hemoglobin ( $p$ value 0,00$)$ dan hematokrit ( $p$-value 0,000 ) terhadap perubahan skor NIHSS (National Institute Health Of Stroke Scale) pada klien stroke iskemik di RSUD di Banjarmasin. Penelitian ini berkesimpulan bahwa kadar hemoglobin dan hematokrit berhubungan dengan derajat klinis penderita stroke iskemik.

Viskositas/kekentalan darah bukan merupakan hal baru dikalangan medis, akan tetapi masih sedikit tenaga medis yang menyadari bahwa viskositas/kekentalan darah banyak ditemukan pada pasien stroke. Menilai viskositas/kekentalan darah membantu penatalaksaanan stroke untuk mengurangi penyebarluasan kerusakan sel-sel otak pada penderita stroke (Waluyo, 2011; Thomas, 1995).

Penelitian ini bertujuan untuk mengetahui karakteristik pasien stroke (jenis kelamin dan usia) dan perbedaan kadar hemoglobin, nilai hematokrit dan jumlah eritrosit pada pasien stroke hemoragik dengan stroke non hemoragik di RSUD dr. H. Abdul Moeloek Provinsi Lampung.

\section{Metode}

Jenis penelitian ini adalah analitik. Penelitian dilaksanakan pada bulan Mei-Juni 2018, di RSUD dr. H. Abdul Moeloek Provinsi Lampung. Variabel bebas dalam penelitian ini adalah stroke hemoragik dan stroke non hemoragik, sedangkan variabel terikatnya adalah kadar hemoglobin, nilai hematokrit dan jumlah eritrosit
Populasi dalam penelitian ini adalah seluruh pasien stroke yang dirawat di RSUD dr. H. Abdul Moeloek Provinsi Lampung, dan yang menjadi sampel adalah pasien stroke yang memenuhi kriteria inklusi dan eksklusi sebanyak 30 orang untuk masing-masing kelompok.

Alat dan bahan yang digunakan dalam pemeriksaan ini adalah handscoon, spuit, ikat tourniquet, tabung darah EDTA, alcohol swab 70\%, leukopik/plester dan alat hematology analyzer (Sysmex Xp-100). Bahan pemeriksaan yang digunakan adalah darah vena pasien stroke hemoragik dan stroke non hemoragik . Pemeriksaan kadar hemoglobin, nilai hematokrit, dan jumlah eritrosit dilakukan dengan alat hematology analyzer (Sysmex Xp100) dilakukan di laboratorium patologi klinik RSUD dr. H. Abdul Moeloek Provinsi Lampung. Untuk melihat perbedaan kadar hemoglobin, nilai hematokrit dan jumlah eritrosit, data diolah dengan menggunakan Uji T Test.

\section{Hasil}

\section{Analisa Univariat}

Tabel 1. Distribusi frekuensi responden berdasarkan jenis kelamin

\begin{tabular}{cccccc}
\hline \multirow{2}{*}{ Jenis stroke } & \multicolumn{5}{c}{ Jenis kelamin } \\
\cline { 2 - 5 } & \multicolumn{2}{c}{ Laki-laki } & \multicolumn{2}{c}{ Perempuan } & Total \\
\cline { 2 - 5 } & $\mathrm{N}$ & $\%$ & $\mathrm{n}$ & $\%$ & \\
\hline $\begin{array}{c}\text { Stroke } \\
\text { Hemoragik }\end{array}$ & 17 & 56.7 & 13 & 43.3 & 30 \\
\hline $\begin{array}{c}\text { Stroke Non } \\
\text { Hemoragik }\end{array}$ & 16 & 53.3 & 14 & 46.7 & 30 \\
\hline
\end{tabular}

Berdasarkan jenis kelamin jumlah pasien stroke hemoragik laki-laki sebanyak 17 pasien (56.7\%), dan perempuan sebanyak 13 pasien (43.3\%). Sedangkan pasien stroke non hemoragik dengan jenis kelamin laki-laki sebanyak 16 pasien $(53.3 \%)$, dan perempuan sebanyak 14 pasien $(46.7 \%)$.

Tabel 2 Distribusi frekuensi responden berdasarkan usia

\begin{tabular}{ccccc}
\hline \multirow{2}{*}{ Usia } & \multicolumn{2}{c}{ Stroke Hemoragik } & \multicolumn{2}{c}{ Stroke Hemoragik } \\
\cline { 2 - 5 } & Frekuensi & $\%$ & Frekuensi & $\%$ \\
\hline$<45$ tahun & 3 & 10.0 & 4 & 13.3 \\
$45-55$ tahun & 11 & 36.7 & 9 & 30.0 \\
$56-65$ tahun & 9 & 30.0 & 8 & 26.7 \\
$>65$ tahun & 7 & 23.3 & 9 & 30.0 \\
Total & 30 & 100 & 30 & 100 \\
\hline
\end{tabular}


Berdasarkan usia, jumlah pasien stroke hemoragik paling banyak adalah pasien berusia 45-55 tahun, yaitu sebanyak 11 pasien (36.7\%), sedangkan pasien stroke non hemoragik yang paling banyak adalah pasien berusia 45-55 tahun sebanyak 9 pasien $(30.0 \%)$ dan berusia $>65$ tahun sebanyak 9 pasien $(30.0 \%)$.

Tabel 3. Distribusi frekuensi kadar hemoglobin, nilai hematokrit dan jumlah eritrosit pada pasien stroke hemoragik Dan pasien stroke non hemoragik

\begin{tabular}{|c|c|c|c|c|}
\hline \multirow[t]{2}{*}{ Variabel } & \multicolumn{2}{|c|}{$\begin{array}{c}\text { Pasien } \\
\text { Stroke } \\
\text { Hemoragik }\end{array}$} & \multicolumn{2}{|c|}{$\begin{array}{c}\text { Pasien Stroke } \\
\text { Non } \\
\text { Hemoragik } \\
\end{array}$} \\
\hline & $\mathbf{N}$ & $\%$ & $\mathbf{n}$ & $\%$ \\
\hline Kadar Hemoglobin & & & & \\
\hline a. Rendah & 12 & 40,0 & 20 & 66,7 \\
\hline b. Normal & 18 & 60,0 & 10 & 33,3 \\
\hline c. Tinggi & 0 & 0,0 & 0 & 0 \\
\hline Nilai Hematokrit & & & & \\
\hline a. Rendah & 14 & 46,7 & 21 & 70 \\
\hline b. Normal & 16 & 53,3 & 9 & 30 \\
\hline c. Tinggi & 0 & 0,0 & 0 & 0 \\
\hline Jumlah Eritrosit & & & & \\
\hline a. Rendah & 11 & 36,7 & 19 & 63,3 \\
\hline b. Normal & 19 & 63,3 & 11 & 36,7 \\
\hline c. Tinggi & 0 & 0,0 & 0 & 0 \\
\hline
\end{tabular}

2. Analisa Bivariat
Data pada tabel 3 menunjukkan hasil pemeriksaan pasien stroke hemoragik dengan kadar hemoglobin normal sebanyak 18 orang $(60 \%)$ dan rendah sebanyak 12 orang $(40 \%)$, nilai hematokrit normal sebanyak 16 orang $(53,3 \%)$ dan rendah sebanyak 14 orang $(46,7 \%)$ dan jumlah eritrosit normal sebanyak 19 orang $(63,3 \%)$ dan rendah sebanyak 11 orang $(36,7 \%)$.

Pada pasien stroke non hemoragik didapatkan kadar hemoglobin normal sebanyak 10 orang $(33,3 \%)$ dan rendah sebanyak 20 orang $(66,7 \%)$, nilai hematokrit normal sebanyak 9 orang $(30,0 \%)$ dan rendah sebanyak 21 orang $(70,0 \%)$ dan jumlah eritrosit normal sebanyak 11 orang $(36,7 \%)$ dan rendah sebanyak 19 orang $(63,3 \%)$. Pada penelitian ini tidak didapatkan hasil pemeriksaan kadar hemoglobin, nilai hematokrit dan jumlah eritrosit yang tinggi, baik pada pasien stroke hemoragik maupun pasien stroke non hemoragik

Hasil pemeriksaan kadar hemoglobin, nilai hematokrit dan jumlah eritrosit pada pasien stroke hemoragik didapatkan lebih banyak yang mempunyai nilai normal dibandingkan dengan nilai/kadar yang rendah. Hal ini sebaliknya dengan pasien stroke non hemoragik, yang mempunyai nilai rendah lebih banyak dibandingkan dengan yang normal.

Tabel 4. Uji T test kadar hemoglobin, nilai hematokrit dan jumlah eritrosit pada pasien stroke hemoragik dan stroke non hemoragik

\begin{tabular}{lcccc}
\hline \multicolumn{1}{c}{ Variabel } & Mean & Std.Error Mean & P-Value & $N$ \\
\hline $\begin{array}{l}\text { Kadar hemoglobin pasien } \\
\text { stroke hemoragik dan stroke } \\
\text { non hemoragik }\end{array}$ & 0.946 & 0.315 & 0.004 & 60 \\
\hline $\begin{array}{l}\text { Nilai hematokrit pasien stroke } \\
\text { hemoragik dan stroke non }\end{array}$ & 2.700 & 0.908 & 0.004 & 60 \\
\begin{tabular}{l} 
Hemoragik \\
\hline $\begin{array}{l}\text { Jumlah eritrosit pasien stroke } \\
\text { hemoragik dan stroke non } \\
\text { hemoragik }\end{array}$
\end{tabular} & 0.246 & 0.107 & 0.026 & 60 \\
\hline
\end{tabular}

Berdasarkan tabel 4 dapat dilihat bahwa $\mathrm{p}$ value kadar hemoglobin $(\mathrm{p}=0.004)$, nilai hematokrit $(p=0.004)$, dan jumlah eritrosit $(p=0.026)$, lebih kecil dari 0.05 . Hasil uji $\mathrm{T}$ test menunjukkan bahwa terdapat perbedaan yang bermakna antara kadar hemoglobin, nilai hematokrit dan jumlah eritrosit pada pasien stroke hemoragik dengan pasien stroke non hemoragik.

\section{Pembahasan}

1.Analisa Univariat

Data pada tabel 1 menunjukkan bahwa pasien stroke hemoragik dengan jenis kelamin laki-laki berjumlah 17 orang (56.7\%) lebih banyak dibandingkan perempuan 13 pasien (43.3\%), demikian juga pada pasien stroke non hemoragik pasien laki-laki sebanyak 16 pasien (53.3\%) lebih banyak dibandingkan perempuan 14 pasien $(46.7 \%)$. Ditemukannya pasien lakilaki lebih banyak dibandingkan pasien perempuan baik pada stroke hemoragik dan stroke non hemoragik dalam penelitian ini, sejalan dengan penelitian Roezwier (2013) dimana hasil penelitian menunjukkan bahwa pasien stroke hemoragik berjumlah 31 orang laki-laki dan 19 pasien perempuan, sedangkan 
pasien non hemoragik berjumlah 34 orang laki-laki dan 16 orang pasien perempuan. Sehingga dapat disimpulkan kejadian stroke lebih banyak dialami laki-laki dibandingkan perempuan.

Banyaknya pasien laki-laki dibandingkan perempuan yang menderita stroke dikarenakan sejumlah faktor yang turut mempengaruhi hal tersebut seperti kebiasaan merokok dan pola hidup yang tidak baik menjadi salah satu pemicu penyakit stroke. Risiko hipertensi dan hiperkolesterol juga turut mendongkrak tingginya risiko pada laki-laki. Risiko terjadinya stroke pada laki-laki 1,3 kali lebih tinggi dibandingkan perempuan (Junaidi, 2011; Lingga, 2013). Hal ini sesuai dengan data penelitian, bahwa pasien laki-laki berjumlah 33 pasien $(100.0 \%)$ mengalami hipertensi yang tidak terkontrol dan mengkonsumsi rokok. Faktor lainnya diperkirakan pada wanita terdapat hormon estrogen, yang dapat menyebabkan vasodilatasi pada pembuluh darah dengan meningkatkan pembentukan dan pelepasan nitrit oxide dan protasiklin pada selsel endhotelial, meningkatkan kadar kolesterol HDL sehingga menghambat terjadinya aterosklerosis pada wanita (Soewondo, 2007).

Data pada tabel 2, menunjukkan bahwa usia responden penelitian pasien stroke hemoragik terbanyak yaitu responden dengan rentang usia 45-55 tahun sebanyak 11 pasien $(36.7 \%)$ dan pada pasien stroke non hemoragik terbanyak yaitu responden dengan rentang usia 45-55 tahun sebanyak 9 pasien $(30.0 \%)$ dan $>65$ tahun sebanyak 9 pasien $(30.0 \%)$. Hasil penelitian ini sesuai dengan penelitian Roezwier (2013) di mana responden terbanyak adalah pasien stroke hemoragik pada rentang usia 45-55 tahun sebanyak 20 pasien dan pasien stroke non hemoragik pada rentang usia 45-55 tahun sebanyak 18 pasien.

Menurut hasil Riskesdas pada tahun 2013 yang menyatakan rentang usia pasien stroke berada dikisaran usia 45-65 tahun. Sehingga dapat disimpulkan bahwa stroke merupakan salah satu penyakit gangguan serebrovaskuler yang berhubungan dengan proses degeneratif. Usia merupakan salah satu faktor risiko stroke dimana peningkatan risiko stroke tersebut mulai terjadi pada usia 45 tahun dan seiring dengan penambahan usia. Hal ini disebabkan melemahnya fungsi tubuh secara menyeluruh terutama terkait dengan fleksibilitas pembuluh darah (Lingga, 2013).

Berdasarkan data pada tabel 3, menunjukkan pada pasien stroke hemoragik bahwa kadar hemoglobin dengan nilai rendah sebanyak 12 pasien $(40.0 \%)$ dan nilai normal sebanyak 18 pasien $(60.0 \%)$, sedangkan pada pasien stroke non hemoragik yang memiliki kadar hemoglobin rendah sebanyak 20 pasien (66.7.0\%) dan hasil normal sebanyak 10 pasien (33.3\%). Kadar hemoglobin yang rendah atau tinggi berhubungan dengan risiko tinggi pada penyakit stroke (Panwar dkk,2016). Kadar hemoglobin rendah pada pasien stroke berkaitan dengan luasnya area infark dan peningkatan luas infark, bersamaan dengan faktor-faktor lain seperti usia, jenis kelamin, kadar glukosa dalam darah dan subtipe stroke. Semakin luas area otak yang infark semakin buruk pula gejala klinis yang muncul (Kimberly, dkk,2011).

Kadar hemoglobin rendah bukan menjadi satu-satunya penyebab buruknya status neurologis pada pasien stroke. Terdapat beberapa faktor lain yang juga berpengaruh terhadap buruknya status neurologis pasien stroke seperti usia, jenis kelamin, kadar glukosa dan kadar hematokrit saat masuk rumah sakit, serta kadar leukosit. Beberapa pasien dengan kadar hemoglobin yang tinggi juga memiliki status neurologi yang buruk.

Pasien stroke hemoragik yang memiliki nilai hematokrit rendah sebanyak 14 pasien (46.7\%) dan hasil normal sebanyak 16 pasien (53.3\%), sedangkan pada pasien stroke non hemoragik yang memiliki nilai hematokrit rendah sebanyak 21 pasien $(70.0 \%)$ dan hasil normal sebanyak 9 pasien $(30.0 \%)$. Nilai hematokrit merupakan faktor risiko minor bagi pasien stroke (Kiyohara dkk, 1985). Kadar hematokrit rendah disebabkan oleh berbagai macam sebab, seperti umur yang menua, gagal ginjal kronik, penyakit jantung (sindrom koroner akut), malignancy dan lainnya. Hematokrit yang menurun dapat menyebabkan penyakit stroke yaitu berhubungan dengan sindrom koroner akut yang merupakan faktor risiko terjadinya stroke yang berarti penurunan hematokrit lebih berhubungan dengan perluasan infark (Tanne, dkk, 2010). Pada pasien stroke dengan nilai hematokrit yang normal, faktorfaktor risiko mayorlah yang lebih mendominasi terjadinya stroke (Hutajulu, 2015). Hal ini sesuai dengan penelitian yang dilakukan oleh Kiyohara,dkk di mana dalam penelitiannya menyebutkan bahwa hematokrit yang normal karena merupakan faktor risiko minor (Kiyohara dkk, 1985).

Pasien stroke hemoragik yang memiliki jumlah eritrosit rendah sebanyak 11 pasien (36.7\%) dan hasil normal sebanyak 19 pasien $(63.3 \%)$, sedangkan pada pasien stroke non 
hemoragik yang memiliki jumlah eritrosit rendah sebanyak 19 pasien $(63.3 \%)$ dan hasil normal sebanyak 11 pasien $(36.7 \%)$. Jumlah eritrosit rendah berkaitan dengan penyakit stroke. Hal ini sesuai dengan penelitian Hatamian dkk, 2014. Berdasarkan penelitiannya pada saat terjadinya stroke penurunan kerja pada molekul dan jaringan didalam tubuh dimulai. Berbagai macam faktor termasuk penurunan jumlah eritrosit menyebabkan prognosis pada pembuluh darah arteri pada pasien stroke. Jumlah eritrosit dibawah nilai normal menyebabkan resistensi pada pasien stroke dan menyebabkan terganggunya transportasi oksigen pada organ lain yang dapat menyebabkan sejumlah kegagalan fungsi organ dan kematian.

\section{Analisa Bivariat}

Data pada tabel 4, hasil uji T Test pada ketiga variabel penelitian yaitu kadar hemoglobin, nilai hematokrit dan jumlah eritrosit didapatkan nilai p-value masingmasing yaitu 0.004 ; 0.004 dan 0.026 artinya Ha diterima ( $p$-value $<0.05)$, hal ini menandakan bahwa terdapat perbedaan yang bermakna antara kadar hemoglobin, nilai hematokrit dan jumlah eritrosit pada pasien stroke hemoragik dengan pasien stroke non hemoragik.

Ada beberapa faktor yang menyebabkan orang menjadi lebih rentan atau mudah mengalami stroke, diantaranya faktor hipertensi, stres, merokok, penyakit jantung dan diabetes mellitus.

Faktor resiko berupa hipertensi, hal ini diperkuat dengan fakta dilapangan pada saat penelitian, pasien stroke hemoragik memiliki tekanan darah yang lebih tinggi dibandingkan dengan tekanan darah pasien stroke non hemoragik. Rata-rata tekanan darah pasien stroke hemoragik mencapai 200/120 $\mathrm{mmHg}$ sedangkan pasien stroke non hemoragik 180/100 mmHg. Hipertensi sangat berkaitan dengan kadar hemoglobin, nilai hematokit dan jumlah eritrosit, penyataan ini sesuai dengan penelitian Plange, dkk tahun 2017. Peningkatan tekanan darah memiliki hubungan positif yang signifikan antara kadar hemoglobin, nilai hematokrit dan jumlah eritrosit. Selain itu faktor yang mempengaruhi hipertensi dengan kadar hemoglobin, nilai hematokrit dan jumlah eritrosit adalah umur, jenis kelamin, sirkulasi fibrinogen dan agregasi sel darah merah (Plange dkk, 2017).

Hipertensi merupakan salah satu faktor risiko terbesar pada penyakit stroke, dengan meningkatkan risiko stroke tujuh kali lebih besar dibandingkan dengan orang yang memiliki tekanan darah normal atau rendah. Sebanyak 60 pasien $(100.0 \%)$ responden penelitian diketahui menderita hipertensi yang tidak dikontrol, sehingga memberikan risiko terbesar terjadinya stroke. Hipertensi mempercepat pengerasan dinding pembuluh darah arteri dan mengakibatkan penghancuran lemak pada sel otot polos sehingga mempercepat proses aterosklerosis. Hipertensi berperan dalam proses aterosklerosis melalui efek penekanan pada sel endotel/lapisan dalam dinding arteri yang berakibat pembentukan plak pembuluh darah semakin cepat (Junaidi, 2011). Selain hipertensi, diabetes mellitus dan merokok merupakan factor risiko terbesar terjadinya penyakit stroke, pada responden penelitian sebanyak 22 pasien (36.7\%) juga menderita diabetes melitus dan sebanyak 33 pasien (55\%) mengkonsumsi rokok.

Diabetes mellitus dapat menyebabkan kemungkinan terjadinya stroke. Diabetes mellitus dapat mempercepat terjadinya aterosklerosis pada pembuluh darah diseluruh pembuluh darah akibat dislipidemia begitupula dengan merokok meningkatkan risiko terkena stroke empat kali lipat yang memiliki peranan dalam terjadinya proses aterosklerosis akibat zat kimia dalam rokok dapat menyebabkan adanya kerusakan endotel pembuluh darah yang dapat mengakibatkan pembentukan aterosklerosis (Junaidi, 2011).

Pasien stroke harus menghindari faktorfaktor risiko stroke untuk menghindari keadaan stroke berulang yang mengakibatkan kelumpuhan syaraf yang lebih berat yang dapat memperburuk kondisi tubuh serta rajin melakukan kegiatan terapi pada anggota gerak yang mengalami kelumpuhan.

Penyakit stroke merupakan penyakit terbesar yang menyebabkan kematian, untuk terhindar terjadinya penyakit stroke, seseorang harus menghindari faktor-faktor risiko penyebab stroke seperti hipertensi, diabetes mellitus dan merokok dengan menjaga pola gaya hidup yang sehat dengan mengkonsumsi makanan rendah lemak dan garam, rajin berolahraga dan menghidari atau mengurangi mengkonsumsi rokok.

Simpulan penelitian ini yaitu dari 30 responden pasien stroke hemoragik dengan jenis kelamin laki-laki yaitu sebanyak 17 pasien $(56.7 \%)$, sedangkan pasien dengan jenis kelamin perempuan sebanyak 13 pasien (43.3 \%). Pasien stroke non hemoragik dengan jenis kelamin laki-laki yaitu sebanyak 16 pasien $(53.3 \%)$, sedangkan pasien dengan jenis 
kelamin perempuan sebanyak 14 pasien (46.7\%). Frekuensi responden penelitian berdasarkan usia pasien stroke hemoragik pasien berusia $45-55$ tahun 11 pasien $(36.7 \%)$. Pasien stroke non hemoragik berusia 45-55 tahun sebanyak 9 pasien $(30.0 \%)$. Terdapat perbedaan yang bermakna antara kadar hemoglobin ( $p$-value 0.004), nilai hematokrit (p-value 0.004) dan jumlah eritrosit ( $p$-value 0.026) pada pasien stroke hemoragik dan stroke non hemoragik di RSUD dr. H. Abdul Moeloek Provinsi Lampung.

\section{Daftar Pustaka}

1. Ardhilla, C, Oktaviani, N. DIASKOLJANTROKE. IN AzNa Books. Yogyakarta: 2013.

2. Cinar, Y, Gamze, D, Mustafa, P, Ayse B.C. Effect of Hematocrit on Blood Preasure Via Hyperviscosity.

3. Elsevier Science inc, American Journal of Hypertension [Online Journal] 1999 [diunduh 12 Juli 1999]. tersedia dari: https://www.ncbi.nlm.nih.gov/pubmed/104 $\underline{11372}$

4. Departemen Kesehatan RI 2009, Laporan Hasil Riset Kesehatan Dasar, Riskesdas Indonesia Tahun 2009, Depkes, Jakarta.

5. Departemen Kesehatan RI 2013, Laporan Hasil Riset Kesehatan Dasar, Riskesdas Indonesia Tahun 2013, Depkes, Jakarta.

6. Hutajulu, I, N, Amsar A, T, Fridayenti. Gambaran Hematokrit Pada Pasien Stroke Iskemik Di Rumah Sakit Umum Daerah Arifin Ahmad Provinsi Riau. JOM FK. Riau: 2015

7. Junaidi, I, Dorce Tandung (Ed.). Stroke Waspadai Ancamannya. C.V Andi Offset. Yogyakarta: 2011.

8. Lingga, L. All About Stroke. PT Elex Media Komputindo Gramedia. Jakarta: 2013.

9. Mardjono, M, Priguna, S. Neurologi Klinis Dasar Edisi 10. Dian Rakyat. Jakarta: 2004.
10. Plange JR, Sally M, Kerry et al 2018, Blood Pressure and Haematological indices in Twelve Communities in Ashanti, Ghana, Int J Hypertens.

11. Setiabudy, R 2012, Hemostasis dan Trombosis Edisi Kelima, Badan Penerbit Fakultas Kedokteran Universitas Indonesia, Jakarta.

12. Sholichati, S, Bagus R.S, Warjiman, Pengaruh Kadar Hemoglobin dan Hematokrit terhadap Perubahan Skor NIHSS (National Institute Health Of Stroke Scale) Pada Klien Stroke Iskemik di RSUD di Banjarmasin, Sekolah Tinggi Kesehatan Sari Mulia Banjarmasin, Banjarmasin

13. Soewondo P, 2007, Menopause, Andropause, dan Somatopause Perubahan Hormonal Pada Proses Menua, Buku Ajar Ilmu Penyakit Dalam, IPD FKUI, Jakarta.

14. Sutanto 2007, Cekal Penyakit Modern Hipertensi, Stroke, Jantung, Kolesterol dan Diabetes, Jakarta.

15. WHO 2014, Global Status Report on Noncomunicable Disease. 